\title{
METODE PSIKORELIGIOUS DALAM REHABILITASI (PENDIDIKAN DAN PEMBINAAN KORBAN NAPZA DAN MIRAS)
}

\author{
Aris Try Andreas Putra \\ Institut Agama Islam Negeri (IAIN) Kendari, Sulawesi Tenggara \\ Email:aristryandreasputraaritonda@gmail.com
}

\begin{abstract}
ABSTRAK
Masalab penyalahgunaan NAPZA dan Miras di Indonesia menjadi isu yang hangat diperbincangkan belakangan ini. NAPZA dan miras tersebut selanjutnya menjadi penyakit akblak bagi anak bangsa. Hal tersebut yang mendorong pemerintab secara massif melakukan penanggulangan dan pencegaban terhadap penyalahgunaannya. Bukan hanya pemerintah, lembaga-lembaga pendidikan kbususnya pesantren melakukan usaha pendidikan pembinaan terhadap korban NAPZA dan miras. Pesantren sekarang ini bukan hanya wadah menyiapkan anak mendalami dan menguasai ilmu agama Islam yang diharapkan dapat mencetak kader-kader ulama, namun lebih dari itu sebagai wadah rehabilitasi bagi korban narkoba. Artikel ini akan menjelaskan tentang pembinaan korban NAPZA dan miras di Pondok Inabah XX dengan metode Psikoreligious yang melaksanakan pembinaan berdasarkan kurikulum yang telab disusun. Metode psikoreligious tersebut dilakukan dengan cara 1) mandi taubat, 2) shalat sunat, 3) dan zikir. Dalam pembinaannya di pondok Inabab XX tersebut menerapkan beberapa pendekatan: 1) Tahap pendekatan 2) tahap pembinaan awal 3) tahap pembentukan sikap 2) tahap akbir.
\end{abstract}

Kata Kunci: Metode Psikoreligious, Pembinaan, Korban NAPZA

\begin{abstract}
The problem of drug and alcohol abuse in Indonesia became a hot issue discussed lately. Drug and alcohol then become a moral disease for nations. This has prompted the government massively conduct reduction and prevention against abuse. Not only the government, educational institutions, especially schools conduct education efforts provide guidance to victims of drug and alcohol. Pesantren now not only container prepare the child to explore and master the science of Islam, which is expected to print a cadre of scholars, but more than that as a container for the rehabilitation of drug addicts. This article will explain about coaching victim of drug and alcohol in Pondok Inabah XX with Psikoreligious methods that implement guidance based curriculum that has been developed. Psikoreligious method is done by 1) bathing repentance, 2) prayer circumcision, 3) and dhikr. In its development in the XX Inabah lodge to several approaches: 1) Phase 2 approach) early development stage 3) stages of the formation of attitudes 2) the final stage.
\end{abstract}

Keywords: Methods Psikoreligius, guidance, Victims of Drug

\section{PENDAHULUAN}

Pondok pesantren sebagai lembaga pendidikan Islam yang memiliki akar kuat pada masyarakat muslim Indonesia, dalam perkembangannya dapat mempertahankan keberlangsungan dirinya serta memiliki model pendidikan multi dimensi. Sejak awal pertumbuhannya, fungsi utama pesantren adalah menyiapkan santri mendalami dan menguasai ilmu agama Islam yang diharapkan dapat mencetak kader- kader ulama dan turut mencerdaskan masyarakat Indonesia dan melakukan dakwah menyebarkan agama Islam serta benteng pertahanan umat dalam bidang akhlak. ${ }^{1}$

${ }^{1}$ Tim Direktorat Jenderal Pembinaan Kelembagaan Agama Islam, Profil Pondok Pesantren Mu'adalab (Jakarta: Direktorat Pendidikan Keagamaan dan Pondok Pesantren Departemen Agama, 2004), h. 3 
Pada kenyataannya fungsi pendidikan tersebut juga diarahkan pada pembinaan dan rehabilitasi. Fungsi rehabilitasi tersebut seperti yang dilakukan pada pesantren Suryalaya di Tasikmalaya, pesantren yang memiliki fungsi sangat unik yaitu sebagai wadah rehabilitasi korban narkoba dan miras.Selanjutnya dikenal dengan Inabah.Pondok Remaja Inabah Suryalaya didirikan oleh KH. Ahmad Shohibul Wafa Tajul Arifin lebih dikenal dengan nama "Abah Anom". Berdirinya pondok inabah Suryalaya ini dilatari oleh kondisi masyarakat yang telah terjerumus dalam dunia NAPZA dan miras.

Proses pembinaan dengan menggunakan metode religi keagamaan (psikoreligious) secara kontinyu terhadap korban NAPZA dan miras berhasil. Atas dasar banyaknya pasien yang makin bertambah tersebut, maka pondok pesantren membentuk satu pondok rehabilitasi dibawah yayasan serba bakti pondok pesantren suryalaya yang diberinama pondok Inabah. Dalam paper ini akan digambarkan metode psikoreligious dalam rehabilitasi dan dihubungkan dengan tahap mistis dalam strategi kebudayaan van peursen, dengan mengambil sampel di Pesantren Suryalaya: Pondok Inabah XX, dengan melihat bagaimana metode psikoreligious, sistem pembinaan dan kurikulum pondok dalam melakukan rehabilitasi.

\section{Asal Usul Sistem Pesantren di Indonesia}

Secara terminologis dapat dijelaskan bahwa pendidikan pesantren, dilihat dari segi bentuk dan sistemnya, berasal dari India. Sebelum proses penyebaran Islam di Indonesia, sistem tersebut telah dipergunakan secara umum untuk pendidikan dan pengajaran agama Hindu di Jawa. Setelah Islam masuk dan tersebar di Jawa, sistem tersebut kemudian diambil oleh Islam. Istilah pesantren sendiri seperti halnya mengaji bukanlah berasal dari istilah arab, melainkan India. Demikian juga dengan istilah podok, langgar di Jawa, surau di Minangkabau dan rangkang di Aceh bukanlah merupakan istilah Arab, tetapi dari istilah yang terdapat di India. ${ }^{2}$

Mengenai sejarah berdirinya pesantren pertama atau tertua di Indonesia terdapat perbedaan pendapat dikalangan peneliti, baik

${ }^{2}$ Karel A. Steenbrink, Pesantren Madrasah Sekolab: Pendidikan Islam dalam Kurun Moderen, Jakarta: LP3ES, 1986), h. 20-21) nama pesantren maupun tahun berdirinya. Berdasarkan hasil pendataan yang dilakukan oleh Depatremen Agama pada 1984-1985 diperoleh informasi bahwa pesantren tertua di Indonesia adalah Pesantren Jan Tanpes II di Pamekasan Madura yang didirikan pada tahun $1762 .^{3}$

Menurut Martin van Bruinessen di dalam Abdullah Aly bahwa Pesantren Tegalsari, salah satu desa di Ponorogo, Jawa Timur merupakan pesantren tertua di Indonesia yang didirikan tahun 1742 M. Silang pendapat tersebut karena kurangnya dokumen/catatan sejarah pesantren yang menjelaskan tentang keberadaan pesantren. Pondok Pesantren terdiri dari dua suku kata, terdiri dari pondok dan pesantren. Kata pondok atau kamar, gubuk, rumah kecil yang dipakai dalam bahasaIndonesia dengan menggambarkan kesederhanaan bangunannya. Kata pondok berasal dari bahasa arab "fundūk" yang berarti ruang tempat tidur atau wisma. Pada umumunya pondok memang merupakan tempat penampungan sederhana bagi para pelajar yang jauh dari tempat asalnya. ${ }^{5}$ Dengan demikian masih tredapat silang pendapat dalam menjelaskan kapan lahirnya dan terbentuknya pesantren.

Nurcholis Madjid dalam bukunya menyatakan bahwa, pesantren sebagai artefak peradaban Indonesia yang dibangun sebagai institusi pendidikan keagamaan bercorak tradisional, unik dan indigeneous. ${ }^{6}$ Selanjutnya pendidikan Pesantren tidak hanya memperkaya murid dengan penjelasan-penjelasan, tetapi juga untuk meninggikan moral, melatih dan mempertinggi semangat, menghargai nilai-nilai spriritual kemanusiaan, mengajarkan sikap yang jujur dan bermoral dan menyiapkan para murit untuk hidup sederhana dan bersih hati.

${ }^{3}$ Departemen Agama RI., Nama dan Data Potensi Pondok-Pondok Pesantren Selurub Indonesia (Jakarta: Depag RI, 1985), h. 668.

${ }^{4}$ Abdullah Aly, Pendidikan Islam Multikultural di Pesantren: Telaab terhadap Kurikulum Pondok Pesantren Modern Islam Assalam Surakarta (Yogyakarta: Pustaka Pelajar, 2011), h. 154-156.

${ }^{5}$ Zamakhsyari Dhofier, Tradisi Pesantren: Studi tentang Pandangan Kyai (Jakarta: LP3ES, 1997), h. 18.

${ }^{6}$ Nurcholis Madjid, Bilik-bilik Pesantren: Sebuah Potret Perjalanan, (Jakarta: Paramadina, 1970), h. 10

${ }^{7}$ Zamaksyari Zhofir, Tradisi Pesantren: Studi tentang 
Pesantren sebagai lembaga pendidikan Islam mengalami perkembangan bentuk sesuai dengan perubahan zaman, terutama adanya kemajuan ilmu pengetahuan dan teknologi. Perubahan bentuk pesantren bukan berarti pesantren kehilangan ciri khasnya.Sistem pesantren adalah sarana yang berupa perangkat organisasi yang diciptakan untuk mencapai tujuan pendidikan yang berlangsung dalam pesantren. ${ }^{8}$ Pesantren mengalami perkembangan fungsi dari waktu ke waktu, berawal dari fungsi edukasi dan dakwah termasuk fungsi rehabilitasi seperti yang akan dijelaskan selanjutnya.

\section{Metode Psikoreligious dalam Rehabilitas di Pondok Inabah XX}

\section{Metode Psikoreligious}

Sebelum menjelaskan tentang metode psikoreligious, terlebih dahulu penulis mengutarakan pemikiran Van Peursen tentang Strategi Kebudayan dan perkembangan kebudayaan manusia. Sebuah strategi kebudayaan akan selalu mencermati ketegangan antara sikap terbuka (transendensi) dengan sikap tertutup (imanensi) dalam hubungan antara manusia dan kekuasaan-kekuasaan disekitarnya. Van Peursen membagi beberapa tahap yang menjelaskan kebudayaan seseorang, yaitu: tahap mitis, tahap ontologis, dan tahap fungsional. Van Peursen mengartikan kebudayaan sebagai manifestasi kehidupan setiap orang dan setiap kelompok orang. Hal mengenai kebudayaan ini menurut van Peursen dibagi menjadi 3 tahap yang bukan berupa tingkatan-tingkatan, melainkan merupakan pandangan-pandangan khusus, yaitu: tahap mitis, tahap onologis dan tahap fungsional. Tahap Mitis, yaitu sikap manusia yang merasakan dirinya terkepung oleh kekuatan-kekuatan gaib di sekitarnya, seperti kekuasaan dewa-dewa alam raya atau kekuasaan kesuburan, seperti dipentaskan dalam mitologi-mitologi yang dinamakan bangsa-bangsa primitif. Sedangkan tahap ontologis adalah yaitu sikap manusia yang tidak lagi hidup dalam kepungan kekuasaan

pandangan hidup Kyai, Jakarta: LP3ES, 1994), h. 21

${ }^{8}$ Arifin, Kapita Selekta Pendidikan Islam dan Umum (Jakarta: Bina Aksara.1995), h. 257 kekuatan mitis, melainkan secara bebas ingin meneliti segala hal. Manusia mengambil jarak terhadap segala sesuatu yang dahulu dirasakan sebagai kepungan. Mereka mulai menyusun suatu ajaran atau teori dasar mengenai hakikat segala sesuatu (ontologi) dan mengenai segala sesuatu menurut perinciannya (ilmu-ilmu). Kebudayaan ontologi berkembang dengan lingkungan kebudayaan kuno yang sangat dipengaruhi oleh filsafat dan ilmu pengetahuan. Berikutnya, tahap fungsional merupakan sikap dan alam pikiran yang tidak begitu terpesona lagi oleh lingkungannya (sikap mitis), ia tidak lagi dengan kepala dingin ambil jarak terhadap objek penyelidikannya (sikap ontologis), ia ingin mengadakan relasi-relasi baru, suatu kebertautan yang baru terhadap segala sesuatu dalam lingkungannya. ${ }^{9}$

Dalam hal ini menurut penulis metode psikoreligius adalah manisfestasi strategi kebudayaan dalam tahap mistis, manusia masih menggunakan metode keagamaan dan keyakinan secara nonempiris. Metode ini dengan menyandarkan substansi kerjanya pada kekuatan gaib, (kekuatan doa, dzikir, mandi taubat dan shalat. Psikologi agama atau dalam bahasa penulis mendekatkan dengan kata (Psikoreligious) tampaknya sudah mulai menyadari potensi-potensi dan daya psikis manusia yang berkaitan dengan kehidupan spiritual. Kemudian menempatkan potensi dan daya psikis tersebut sebagai sesuatu yang penting dalam kehidupan manusia. Selain itu mulai tumbuh suatu kesadaran baru mengenai hubungan anatra potensi dan daya psikis tersebut dengan sikap dan pola tingkah laku manusia. ${ }^{10}$

Menurut Zakiah Darajat bahwa psikologi agama meneliti pengaruh agama terhadap sikap dan tingkah laku orang atau mekanisne yang bekerja dalam diri seseorang, karena cara seseorang berpikir, bersikap, bereaksi dan bertingkah laku tidak dapat dipisahkan dari keyakinannya, karena keyakinan itu masuk dalam kostruksi pribadi. ${ }^{11}$ Selanjutnya Menurut Drajat,

${ }^{9}$ C. A van Peursen, Strategi Kebudayaan, Yogyakarta: Kanisius, 1988, h. 18

${ }^{10}$ Jalaluddin. Psikologi Agama, Rajagrafindo Persada : Jakarta, 2010, h. 258

${ }^{11} \mathrm{Ibid}$ 
bahwa psikologi agama (Psikoreligious) berkaiatan dengan pengaruh agama terhadap sikap dan tingkah laku orang atau mekanisne yang bekerja dalam diri seseorang, karena cara seseorang berpikir, bersikap, bereaksi dan bertingkah laku tidak dapat dipisahkan dari keyakinannya, karena keyakinan itu masuk dalam kostruksi pribadi. ${ }^{12}$

Metode Psikoreligios dalam hal ini yang digunakan di pesantren suryalaya adalah metode Psikoreligious Inabah yang istilah yang berasal dari bahasa arab, anaba-yunibu- yang berarti kembali. Istilah ini digunakan dalam $\mathrm{Al}$ Quran dalam surat Lukman ayat 15; surat al-syura ayat 10. Dalam literaratur kajian ilmu tasawuf dikenal pula dengan istilah Inabah yang berarti kembali kepada Allah; maksudnya adalah mengembalikan orang dari perilaku yang selalu menantang kehendak Allah kepada perilaku yang sesuai dengan kehendak Allah SWT. Istilah ini deikembangkan oleh abah Anom sebagai konsep perawatan korban penyalahgunaan NAPZA dan miras serta konsep perawatan remaja yang nakal dalam berbagai bentuk penyakit kerohanian.

Psikoreligious sebagai suatu metode, berlandaskan pada Al quran, Hadits dan ijtihad para ulama yakni sebagai berikut: para korban penyalahgunaan NAPZA yang bertalian dengan kenakalan remaja serta berbagai bentuk penyakit kerohanian dianggap sebagai orang yang berdosa karena melakukan maksiat. ${ }^{13}$ Orang berdosa dalam islam harus bertaubat. Taubat secara terminologis islam adalah meninggalkan kejelekan disertai rasa penyesalan karena melakukannya serta dibarengi dengan tujuan kuat untuk meninggalkan selamanya.

\section{Tujuan Pembinaan Pecandu Narkoba di Pondok Remaja Inabab $X X$}

Pembinaan pasien Inabah XX Suryalaya ini, yaitu melalui metode terapi keagamaan (psikoreligius) yang bersifat religi. Adapun program-program yang diselenggarakan dalam pembinaan pondok inabah ini adalah tentang metode terapi keagamaan yang diterapkan

${ }^{12}$ Ajat sudrajat dkk, Din Al Islam : Pendidikan Agama Islam di Perguruan Tinggi Umum, Yogyakarta: UNY Pres, 2008, h. 2

${ }^{13}$ Tim Penyusun Buku Inabah: 17, Tasikmalaya,2010 seperti pembinaan shalat, dzikir, mandi taubat dan pembinaan lanjutan lainnya. Dengan adanya program pemulihan yang dilaksanakan di Pondok Pesantren Suryalaya Inabah ini diharapkan dapat merubah prilaku sosial remaja korban penyalahgunaan narkoba ke arah yang lebih baik. Sehingga korban penyalahgunaan narkoba ini dapat menemukan hal-hal yang baru. Pola hidup yang baru dan teratur tanpa narkoba. Proses rehabilitasi di Pondok Pesantren Inabah Putra Suryalaya ini juga meliputi penyembuhan atau proses dalam menangani masalah sosial yang ada melalui pendekatan medis, psikologis, sosial dan spritualnya.

Adapun tujuan pembinaan pecandu narkoba di pondok Remaja Inabah XX ini adalah sbb:

1. Meningkatkan kesadaran pecandu akan bahaya penyelahgunaan narkoba.

2. Menumbuhkan kesadaran pecandu untuk beramal ma'ruf.

3. Memiliki kesadaran sosial kemasyarakatan dan keagamaan dengan melibatkan peran serta semua lapisan masyakat.

4. Mendukung terwujudnya sumber daya manusia/ generasi muda yang bangsa yang bebas dari bahaya narkoba.

5. Pengikhlasan dan kesadaran beragama, peningkatan ibadah sebagai umat Islam kepada Allah SWT. ${ }^{14}$

\section{Metode Pembinaan di Pondok Remaja Inabah XX \\ Tahap Awal Pembinaan}

Pada awal pembinaan dimana anak diserahkan oleh orang tuanya untuk dibina dan disadarkan, telebih dahulu pembina mewawancarai orang tua maupun calon anak bina, hal ini dimaksudkan:

1) Untuk mengetahui sejauh mana tingkaya keterlibatannya dalam penyalahgunaan NAPZA

2) Untuk mengetahui tingkat ketergantungannya pada NAPZA

3) Untuk mengetahui jenis NAPZA yang dipakai. ${ }^{15}$

${ }^{14}$ Sekretariat Pondok Inabah XX, Dokumentasi, Tasikmalaya, Tanggal 17 Juni 2012

${ }^{15}$ Sekretariat Pondok Inabah XX, Dokumentasi, Tasikmalaya, Tanggal 17 Juni 2012 
Tahap berikutnya setelah diketahui tingkat ketergantungan dan jenis NAPZA langkah selanjutnya adalah:

1) Calon anak bina dimandikan dengan istilah mandi taubat, yang tujuannya adalah untuk memberikan sugesti untuk bertaubat dan menurunkan kadar dari ketergantungannya. Disamping itu, apabila kadar ketergantungannya masih tinggi juga diberikan minum air asam jawa (campur gula merah) atau air kelapa muda, hal ini dimaksudkan untuk menurunkan kadar radiasi NAPZA yang dalam tubuh dan mengurangi ketergantugannya, sehingga diharapkan racun-racun dalam tubuh akan keluar.

2) Setelah mandi atau dimandikan keesekan harinya secepatnya dibawa kepada yang ditugaskan oleh abah Anom untuk menyadap Ilmu Tasauf Islam melalui “Talqin Dzikir”.

3) Selanjutnya setelah ditalqin dzikir anak bina tersebut dibawa kembali ke pondok Inabah XX untuk mengikuti proses pembinaan sesuai dengan kurikulum yang telah diprogramkan.

Berdasarkan pengalaman pembina para remaja korban NAPZA di pondok Inabah XX dikategorikan ke dalam 2 jenis yaitu:

1) Kategori satu, dimana anak tersebut sebagai peminum minuman keras, pemakai pil/obat, dan penghisap ganja. Efeknya yaitu kelakuan anak tersebut selalu berkata bohong, minat belajarnya hampir tidak ada.

2) Kategori dua, dimana anak tersebut disamping menggunakan minuman keras, pil/obat, ganja, juga meggunakan morfin, heroin, termasuk didalamnya putaw dan sabu-sabu. Efeknya yaitu selain efek pada poin 1 di atas, juga mereka kehilangan kontrol (buang air tidak terkendali lagi).

Selanjutnya untuk lamanya pelaksanaan pembinaan disesuaikan dengan tingkat ketergantungannya sebagai berikut:

1) Untuk kategori pertama lama pembinaannya antara 40 sampai 90 hari.

2) Untuk kategori kedua lamanya antara 1 sampai 2 tahun.
Metode Pembinaan terhadap korban Penyalahgunaan NAPZA (Narkotika, Psikotropika dan Zat Adiktif lainnya)

Program kegiatan yang ada di pondok remaja inabah XX putra Suryalaya adalah dengan metode terapi keagamaan (Psikoreligius) yaitu:

\section{Mandi Taubat}

Mandi ini dilaksanakan dengan niat taubat atau menghilangkan berbagai dosa dari seluruh anggota tubuh, mulai dari ujung rambut sampai ujung kaki. Caranya dengan mengalirkan air ke seluruh permukaan tubuh, dari atas ke bawah secara merata, dan dilaksanakan sekitar pukul: 02.00 dini hari. Fungsi mandi secara fisik adalah untuk menormalkan fungsi syaraf yang kurang normal untuk membangun kesadaran diri dari gangguan mabuk, marah yang berlebihan atau kesurupan. Anak bina yang baru datang masuk ponpes inabah XX putra Suryalaya biasanya langsung dimandikan, oleh seorang pembina dituntun dengan membaca doa Mandi taubat ${ }^{16}$. Adapun doa nya adalah sebagai berikut: Robbi anzilni munzalan mubbaa rokan wa anta kboirul munziliin. Terjemahannya: "Ya Tuhanku, tempatkanlah aku pada tempat yang diberkati,dan engkau adalah Sebaik-baik yang memberi tempat."

\section{Shalat}

Amalan shalat menjadi metode penyadaran diri yang sangat diutamakan, baik shalat wajib maupun shalat sunat. Khusus untuk penyembuhan atas ketergantungan narkoba, amalan shalat dikerjakan dengan peraturan yang sangat ketat. Semua jenis shalat baik yang wajib atau pun yang sunat yang ditetapkan dalam kurikulum Inabah, diberlakukan sebagai kewajiban yang harus dilaksanakan bagi seluruh anak bina. Dengan demikian dalam sehari semalam, seluruh anak bina melaksanakan amalan shalat sebanyak 82 rakaat.

Dalam shalat, baik wajib ataupun sunat, terdapat beberapa metode yang mampu mengobati beberapa penyakit lahiriah dan penyakit batiniah antara lain gerakan-gerakan yang dilakukan dalam shalat merupakan medis yang sangat dianjurkan,

${ }^{16}$ KH. Ma'mun Suhendi, Pimpinan Pondok, Wawancara, Tasikmalaya, 17 Juni 2012, pukul 09.50 
sedangkan bacaan-bacaan dalam shalat merupakan suatu terapi yang mampu membersihkan hati kita dari syeitan. Shalat ini diyakini memiliki daya penyadar yang sangat besar, untuk itu selain shalat wajib sehari semalam, intensitasnya diperbanyak dengan melaksanakan berbagai shalat sunat.

Selain manfaat psikologis yang bersifat terapi shalat juga mempunyai manfaat somatic atau psikosomatic. Hal ini disebabkan karena secara mekanis gerakan dalam shalat memiliki aspek olahraga dan akupuntur yang bersifat terapi. ${ }^{17}$ Adapun Dasar firman Allah dalam surat al-Ankabut: 45 yang berbunyi: Innas shalaata tanha anil fahsyaa iwal munkar Terjemahannya: "Sesunggubnya shalat itu mencegab dari (perbuatanperbuatan) keji dan munkar.

\section{Dzikir}

Dzikir merupakan metode yang paling ampuh dalam hal mendekatkan diri pada Allah SWT karena dengan berdzikir semua syetan dan iblis akan menyingkir dari hadapan manusia. Dzikir yang dilakukan dalam shalat dimaksudkan untuk beribadah kepada Allah SWT dengan konsep toqorub sekaligus memberikan pengalaman batin dan mengisi rohani dengan kalimat tauhid agar hati kita senantiasa berisi asma Allah SWT dan mendapat kenikmatannya. Dari hadits dikatakan tentang manfaat dzikir ini sebagai berikut:

Terjemahnya: "Sesunggubnya bagi setiap segala sesuatu itu ada alat pembersibnya, dan sesunggubnya alat pembersib hati (jiwa) adalab dzikir kepada allah. Dan tidak ada sesuatu yang lebib dapat menyelamatkan dari siksaan Allab dari pada Dzikrullah. (H.R.Baihaqi)

Kenikmatan itulah yang dapat mengalihkan kenikmatan pecandu dari obat-obatan kepada kenikmatan ilahiyah. Dzikir TQN dimaksud adalah dzikir yang memakai aturan yang terkandung dalam al-quran dan al hadist. Dzikir ini dibagi 2 bagian :

${ }^{17}$ KH. Ma'mun Suhendi, Pimpinan Pondok, Wawancara, Tasikmalaya, 17 Juni 2012, pukul 09.56
Dzikir Zahar (dzikir yang diucapkan dengan suara keras).

Cara melakukan dzikir tersebut adalah sebagai berikut: Berdzikir mulai dengan ucapan laa dari bawah pusat dan diangkat sampai ke otak dalam kepala sesudah itu diucapkan ilaaha dari otak dengan menurunkan perlahan ke bahu kanan, lalu memulainya lagi illallah dari bahu kanan dengan menurunkan kepala kepada pangkal dada di sebelah kiri dan berkesudahan pada hati sanubari di bawah tulang rusuk lambung dengan menghembuskan lafadz nama Allah SWT sekuat mungkin sehingga terasa gerakannya pada seluruh badan seakan-akan di seluruh bagian badan amal yang rusak itu terbakar dan memancarkan nur Tuhan. Laa Ilaaha Illallah. ${ }^{18}$

\section{Dzikir Khofi}

Dzikir Khofi Ialah dengan memejamkan mata bibir dirapatkan lidah dilipat ke langit-langit gigi dirapatkan tiada bergerak dan menahan nafas sedangkan hati tiada berhenti berdzikir.

\section{Kurikulum Pondok Remaja Inabah XX}

Dalam melakukan pembinaan para Anak Bina sebagaimana disebutkan ada tiga amalan pokok sebagai standar utama, yaitu: mandi, shalat dan zikir dengan metode TQN yang dilaksanakan secara istiqamah dan berkelanjutan sehari semalam, dengan jadwal seperti pada Tabel.

\section{KESIMPULAN}

Berdasarkan pembahsan sebelumnya dapat disimpulkan beberapa poin sebagai berikut:

Fungsi rehabilitasi di pesantren Suryalaya bertujuan untuk malakukan pembinaan moral dan perawatan dan pembinaan masyarakat yang memiliki kertergantungan pada NAPZA dan Miras.

Metode Psikoreligios yang dalam tahap perkembangan kebudayaan manusia Van Peursen berada dalam tahap mistis, dalam hal ini yang digunakan di pesantren suryalaya adalah metode Psikoreligious Inabah yang istilah yang berasal dari bahasa arab, anaba-yunibu- yang berarti kembali.

${ }^{18}$ KH. Ma'mun Suhendi, Pimpinan Pondok, Wawancara, Tasikmalaya, 17 Juni 2012, Pukul 10.11 


\begin{tabular}{|c|c|c|c|}
\hline Jam & Kegiatan & Satuan & Keterangan \\
\hline $02.00-04.00$ & $\begin{array}{ll}\text { 1. } & \text { Bangun, mandi taubat, dan wudhu } \\
\text { 2. } & \text { Shalat sunat syukrul-wudhu. } \\
\text { 3. } & \text { Shalat sunat tahiyatul masjid } \\
\text { 4. } & \text { Shalat sunat taubat } \\
\text { 5. } & \text { Shalat sunat tahajud } \\
\text { 6. } & \text { Shalat sunat tasbih } \\
\text { 7. } & \text { Shalat sunat witir } \\
\text { 8. } & \text { Dzikir jahar/khofi sampai subuh } \\
\end{array}$ & $\begin{array}{c}- \\
32 \\
2 \\
2 \\
12 \\
4 \\
11 \\
\text { Min } 165\end{array}$ & $\begin{array}{l}\text { Rakaat } \\
\text { Rakaat } \\
\text { Rakaat } \\
\text { Rakaat } \\
\text { Rakaat } \\
\text { Rakaat } \\
\text { Kali }\end{array}$ \\
\hline $04.00-04.30$ & \begin{tabular}{|c|} 
ISTRAHAT \\
\end{tabular} & & Coffe Break \\
\hline $04.30-05.30$ & \begin{tabular}{|ll} 
1. & Shalat sunat Syukrul Wudhu \\
2. & Shalat sunat qabla subuh \\
3. & Shalat sunat lidafil bala \\
4. & Shalat subuh \\
5. & Dzikir jahar/khofi \\
6. & Khataman \\
\end{tabular} & $\begin{array}{c}2 \\
2 \\
2 \\
2 \\
\operatorname{Min} 165 \\
1 \\
\end{array}$ & $\begin{array}{c}\text { Rakaat } \\
\text { Rakaat } \\
\text { Rakaat } \\
\text { Rakaat } \\
\text { Kali } \\
\text { Kali }\end{array}$ \\
\hline $05.30-06.00$ & Hafalan Bacaan Zikir & & \\
\hline $06.00-06.15$ & \begin{tabular}{|ll} 
1. & Shalat sunat isyraq \\
2. & Shalat sunat istiazah \\
3. & Shalat sunat istikharah \\
\end{tabular} & $\begin{array}{l}2 \\
2 \\
2\end{array}$ & $\begin{array}{l}\text { Rakaat } \\
\text { Rakaat } \\
\text { Rakaat }\end{array}$ \\
\hline $06.15-07.00$ & Sarapan Pagi & & \\
\hline $07.00-08.00$ & Olahraga & & \\
\hline $08.00-09.00$ & Istrahat & & Tidur, Nonton TV \\
\hline $09.00-10.30$ & $\begin{array}{ll}\text { 1. } & \text { Shalat sunat Syukrul Wudhu } \\
\text { 2. } & \text { Shalat sunat Dhuha } \\
\text { 3. } & \text { Shalat sunat kifaratul bauli } \\
\text { 4. } & \text { Dzikir } \\
\text { 5. } & \text { Hafalan Doa-doa } \\
\end{array}$ & $\begin{array}{c}2 \\
8 \\
2 \\
\text { Min } 165\end{array}$ & $\begin{array}{c}\text { Rakaat } \\
\text { Rakaat } \\
\text { Rakaat } \\
\text { Kali } \\
\text { Bacaan Shalat }\end{array}$ \\
\hline $10.30-11.00$ & Istrahat & & Coffe Break \\
\hline $11.00-11.30$ & Mandi & & Sebelum Shalat Zuhur \\
\hline $11.30-12.15$ & $\begin{array}{ll}\text { 1. } & \text { Shalat sunat syukru wudhu } \\
\text { 2. } & \text { Shalat sunat Qabla dhuhur } \\
\text { 3. } & \text { Shalat fardhu dzuhur } \\
\text { 4. } & \text { Dzkir jahar/khofi } \\
\text { 5. } & \text { Shalat sunat ba'da zuhur } \\
\end{array}$ & $\begin{array}{c}2 \\
2 \\
4 \\
165 \\
2 \\
\end{array}$ & $\begin{array}{c}\text { Rakaat } \\
\text { Rakaat } \\
\text { Rakaat } \\
\text { Kali } \\
\text { Rakaat } \\
\end{array}$ \\
\hline $12.15-13.00$ & Makan Siang & & \\
\hline $13.00-14.30$ & Istrahat & & Tidur Siang \\
\hline $14.30-15.00$ & Mandi & & Sebelum Shalat Ashar \\
\hline $15.00-16.30$ & $\begin{array}{ll}\text { 1. } & \text { Shalat sunat Syukru Wudhu } \\
\text { 2. } & \text { Shalat sunat qabla ashar } \\
\text { 3. } & \text { Shalat fardhu ashar } \\
\text { 4. } & \text { Dzikir khofi/jahar } \\
\text { 5. } & \text { Khataman } \\
\text { 6. } & \text { Hafalan dan Membaca Al Qur'an } \\
\end{array}$ & $\begin{array}{c}2 \\
2 \\
4 \\
165 \\
1\end{array}$ & $\begin{array}{c}\text { Rakaat } \\
\text { Rakaat } \\
\text { Rakaat } \\
\text { Kali } \\
\text { Kali }\end{array}$ \\
\hline $16.30-17.30$ & Istrahat & & \\
\hline $17.30-18.00$ & Mandi & & Sebelum Shalat Maghrib \\
\hline $18.00-19.00$ & \begin{tabular}{|ll} 
1. & Shalat sunat Syukru Wudhu \\
2. & Shalat sunat maghrib \\
3. & Shalat fardhu magrib \\
4. & Dzkir jahar/khofi \\
5. & Khataman \\
6. & Shalat sunat ba'da maghrib \\
7. & Shalat sunat awwabin \\
8. & Shalat sunat taubat \\
\end{tabular} & $\begin{array}{c}2 \\
2 \\
3 \\
165 \\
\\
2 \\
6 \\
2 \\
\end{array}$ & $\begin{array}{c}\text { Rakaat } \\
\text { Rakaat } \\
\text { Rakaat } \\
\text { Kali } \\
\text { Sesuai panduan } \\
\text { Rakaat } \\
\text { Rakaat } \\
\text { Rakaat } \\
\end{array}$ \\
\hline
\end{tabular}


sambungan dari tabel halaman 73

\begin{tabular}{|c|c|c|c|}
\hline Jam & Kegiatan & Satuan & Keterangan \\
\hline & $\begin{array}{l}\text { 9. Shalat sunat birul walidain } \\
\text { 10. Shalat sunat hifdhul iman } \\
\text { 11. Shalat sunat li syukril-ni'mah }\end{array}$ & $\begin{array}{l}2 \\
2 \\
2\end{array}$ & $\begin{array}{l}\text { Rakaat } \\
\text { Rakaat } \\
\text { Rakaat }\end{array}$ \\
\hline $19.00-19.30$ & $\begin{array}{l}\text { 1. Shalat sunat qabla isya } \\
\text { 2. Shalat fardhu isya } \\
\text { 3. Shalat sunat ba'da isya } \\
\text { 4. Dzikir jahar/khofi } \\
\text { 5. Shalat Sunat Lidaf'al Bala }\end{array}$ & $\begin{array}{c}2 \\
4 \\
2 \\
165 \\
2\end{array}$ & $\begin{array}{c}\text { Rakaat } \\
\text { Rakaat } \\
\text { Rakaat } \\
\text { Kali } \\
\text { Rakaat }\end{array}$ \\
\hline $19.30-21.00$ & Istrahat & & \\
\hline $21.00-21.30$ & $\begin{array}{l}\text { Shalat sunat Syukrul Wudhu } \\
\text { Shalat sunat mutlaq } \\
\text { Shalat sunat hajat } \\
\text { Dzikir }\end{array}$ & $\begin{array}{c}2 \\
2 \\
2 \\
165\end{array}$ & $\begin{array}{c}\text { Rakaat } \\
\text { Rakaat } \\
\text { Rakaat } \\
\text { Kali }\end{array}$ \\
\hline $21.30-02.00$ & Istrahat & & $\begin{array}{l}\text { Anak bina tidur hingga } \\
\text { pukul } 02.00\end{array}$ \\
\hline
\end{tabular}

Sumber Data: Sekretariat Pondok Remaja Inabah XX, Puteran, Tasikmalaya

Metode Psikoreligious berhubungan dengan pengaruh agama (Mandi Taubat, shalat, Dzikir) terhadap sikap dan tingkah laku orang.

Metode yang digunakan dalam pembinaan dan perawatan adalah dengan metode Psikoreligious dengan (mandi taubat, shalat, Dzikir), berdasarkan pada kurikulum pondok Inabah, dilakukan secara teratur dan terjadwal.

Dalam pembinaannya di pondok Inabah menerapkan beberapa tahap pendekatan: 1) Tahap pendekatann 2) tahap pembinaan awal 3) tahap pembentukan sikap 2) tahap akhir.

\section{DAFTAR PUSTAKA}

Arifin, Kapita Selekta Pendidikan Islam dan Umum, Jakarta: Bina Aksara, 995

Aly, Abdullah, Pendidikan Islam Multikultural di Pesantren: Telaab terhadap Kurikulum Pondok Pesantren Modern Islam Assalam Surakarta Yogyakarta: Pustaka Pelajar, 2011

Departemen Agama RI., Nama dan Data Potensi Pondok-Pondok Pesantren Selurub Indonesia (Jakarta: Depag RI, 1985
Dhofier, Zamakhsyari, Tradisi Pesantren: Studi tentang Pandangan Kyai, Jakarta: LP3ES, 1997

Jalaluddin. Psikologi Agama, Rajagrafindo Persada : Jakarta, 2010

Madjid, Nurcholis, Bilik-bilik Pesantren: Sebuah Potret Perjalanan,Jakarta: Paramadina, 1970

Ramayulis, Psikologi Agama, Kalam Mulia, 2004

Steenbrink, Karel A., Pesantren Madrasab Sekolab: Pendidikan Islam dalam Kurun Moderen, Jakarta: LP3ES, 1986

Sudrajat, Ajat dkk, Din Al Islam : Pendidikan Agama Islam Diperguruan Tinggi Umum, Yogyakarta: UNY Pres, 2008

Peursen, C. A van, Strategi Kebudayaan, Yogyakarta: Kanisius, 1988

Tim Direktorat Jenderal Pembinaan Kelembagaan Agama Islam, Profil Pondok Pesantren Mu'adalah, Jakarta: Direktorat Pendidikan Keagamaan dan Pondok Pesantren Departemen Agama, 2004

Tim Penyusun, Buku Inabab: 17, Tasikmalaya,2010 Zhofir, Zamaksyari, Tradisi Pesantren: Studi tentang pandangan Hidup Kyai, Jakarta: LP3ES, 1994 